\title{
Students Comprehension To The New Terminology of Covid-19
}

\author{
Aminnudin Saimon $^{1}$ (D), Nazatul Aineena Abdul Latif ${ }^{2}$ (D), Nazihah Abd Rahim ${ }^{3}$ (D), Ainul Insyirah Mohd Yusoff ${ }^{4}$ (D), \\ Nur Syazani Hanis Mohammad ${ }^{5}$ (D) \\ 1,2,3,4,5 Kulliyyah of Languages and Management, International Islamic University Malaysia (IIUM) Pagoh, Johor, Malaysia.
}

\begin{abstract}
Keywords:

New Terminology, COVID-19,

Comprehension Level,

Press Conference,

Malay Language.

Received Date:

Accepted Date:

27-04-2021

Publication Date:

29-04-2021

Purpose of Study: The pandemic that hit the world at this time has led to the existence of new terms COVID-19 in society. This study aims to find out the use of new terms in the COVID-19 press conference.

Methodology: This study is a quantitative study that uses a survey method which is a questionnaire used to identify new terms in the COVID-19 press conference and examine the level of student knowledge of terms in the COVID-19 press conference.

Main Finding: A total of 200 students from four public universities were selected using stratified random sampling. The findings of the study found that UIAM students make a higher comprehensive, followed by UPSI, UKM, and UM students. The total is 3952, UIAM students take the first as 1001 comprehensive of COVID-19 terminology followed by UPSI (998), UKM (995), and UM (958). The terms of R-Naught, Surveying Activities, and Triaging is the newest terminology not understood by all students from all chosen universities. The final finding shows that students comprehensive are really good toward the new terminology of the COVID-19 pandemic.

Research Implication: The implication from this research would like to give some more information to the community about terminology. This research also enhanced the lexicon of the Malay language, thus helping the Malay language to subscribe and describe the new terminology to the other fields.

The novelty of This Study: Based on the research, this paper is the new novelty would like to seek comprehensive students toward the COVID-19 terminology.
\end{abstract}

\section{INTRODUCTION}

Pandemic COVID-19 that hit the world has opened up a space diversity from the point of translation and the corresponding term matches the Malay language that was introduced by the Ministry of Health (MOH) and Dewan Bahasa dan Pustaka (DBP). In the context of terminology, this pandemic has added new terminology in all languages around the world, including Malay, which also demanded the creation of a new term. In the community, new terms emerged mainly during the COVID-19 epidemic. The concepts and ideas in various fields including the field of public health, which are mostly taken from English, are said to be difficult to be translated or expressed in language. Therefore, many new concepts, each of which needs to be constructed or coined, cause the widespread borrowing of foreign terms. In the procedure for the establishment of the Malay language terms, the drafters of the term were given leeway to borrow foreign terms on the condition that a foreign term borrowed more suitable means, shorter-term, and can facilitate coordination (Mohamad, Malek, \& Abd. Razak, 2020). However, the production of new vocabulary or terminology in line with current developments will certainly strengthen the Malay language. Let the Malay language terms continue to grow, but its development must be controlled, not blocked, and censored, by following the original purpose of language planning (Kasdan, Baharuddin, \& Shamsuri, 2020). Therefore, this study is generally about the use of new terms and examines the level of knowledge of the community especially students on terms in the COVID-19 press conference.

Understanding a new, lexical term is not an easy task. An understanding of a term needs to go through various methods, including understanding its pronunciation, meaning, and usage in context (Kasdan et al., 2020). Looking at the situation of the COVID19 pandemic, various new terms were introduced in line with the spread of the pandemic. Problems arise when students do not understand the meaning and use of new terms in COVID-19 even though the term is already widely used. This issue related to the statement of Mohamad et al. (2020) that most of the words were brought in from foreign terms and then modified their language form according to the guidelines for the formation of existing terms to talk about new fields. However, some terms are formed using the inventive use of the Malay language entirely. Some linguists argue that this process contributes to the enrichment or increase of Malay vocabulary, and reflects the thinking of the society which is expanding rapidly through the listing of the various specialized vocabulary in various fields of science. This has caused doubts or confusion among users of the term while using the term. Some people do not know directly about it even though the term is often used during the COVID19 press conference and has been introduced by the Ministry of Health Malaysia (MOH) and Dewan Bahasa dan Pustaka (DBP).

${ }^{1}$ Corresponding Author: deanamin@iium.edu.my 
Therefore, starting understanding issues, the problem that arises is the use of new terms in COVID-19 is already widely used, but student's understanding of the term COVID-19 is still lacking.

Lack of studies describing the general term in the text or scientific language of Malay language can be seen from literature or previous studies that show that most of the studies focused on other aspects, such as the method of forming terms by Radzi

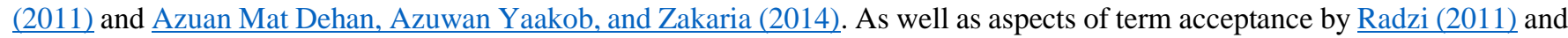
Fage-Butler and Jensen (2015) understanding the terms is very important because the terms used will have a big impact on the mastery of vocabulary and intellectuals of a person especially students. Therefore, an understanding of terms needs to be mastered because the terms formed are based on current issues or phenomena that occur. Students in particular need to take note of the issues and phenomena that occur.

\subsection{Research Objective}

In this research, researchers state two main objectives to achieve the research goals. The objectives in this research are;

a. To identify the new terminology in COVID-19

b. To identify students comprehension toward terms of COVID-19

\subsection{Research Question}

Based on problem statements and research objectives, researchers state two main research questions for answering and solving the issues. The research question is;

a. What is the new terminology in COVID-19?

b. How student comprehension of the new terms of COVID-19 is?

\section{LITERATURE REVIEW}

\subsection{Concept of Terminology}

The applicable terms of health sciences in general and parses text corpus term in terms of frequency of occurrence of a term in common corpus language (Mohamad et al., 2020). This study uses text analysis methods involving medical corpus as text corpus. The findings of the study found that the use of complex terms in newspapers is lower when compared to common words. According to the study, newspaper texts were found to use language that is easy to understand and provide additional information on a term in more detail and latest. The appearance of the term in various fields contributes to the enrichment of the French language and vocabulary is very important in supporting the development of the Malay language as the language of science. However, the study of common terms in the text of the Malay language is still quite low. Most studies focus on aspects of term formation as well as aspects of term acceptance. Moreover, the phenomenon of dumping foreign terms in the vocabulary of the Malay language, especially in the field of science and technology also shows that people are often coined the term easily through the absorption of foreign terms for current needs. Thus, this study describes the creation of the term in the text field of medicine (health sciences) language. The first objective is to identify the term health science in the general text, i.e. the newspaper. Methods used in the identification of the term are to make comparisons between terms in the general text and data banks existing term, a term in the Malay Literary Reference Center (Pusat Rujukan Persuratan Melayu), Dewan Bahasa dan Pustaka. An analytical approach is used to explain terms in a text through words used as clues by general text writers. The second objective is to describe the terms of the corpus in terms of frequency of occurrence of a term in common corpus language. Next, the relationship of the term with the existing term is described based on the form of the term produced as well as the description in the text studied. This study uses text analysis methods involving the corpus of medical texts (health sciences) from online newspapers, namely Berita Harian, Harian Metro, Utusan, Kosmo, and Info Sihat from January 2015 to February 2018, involving 41000 words. TextStat analyzer text system is used to display study data in the form of word frequency and concordance for term identification. The study was to document the medical term health sciences Malay various user-related fields and methods of formation. This study is useful to prove that terms created by users quickly through general text can meet the requirements of standard terms in the field of health sciences.

Research conducted by Kasdan et al. (2020) aims to analyse and describe the phenomenon of the creation of terms about COVID19. The data of this research is obtained from the terms used in the text of the press statement of the Ministry of Health Malaysia $(\mathrm{MOH})$. The results of the research show that $67.0 \%$ (96) terms used by the MOH have been standardized by DBP. However, some terms are indeed new but the formation is found to meet the guidelines for the formation of terms. From a linguistic perspective, this pandemic will germinate corpus Malay vocabulary very fast. For example, there are terms of social imprisonment, droplet, PPE, PKP, and level at the top of the curve. There are even various terms to refer to a common concept, such as delinquency and de-virus, as well as the rate of increase in cases and the surge in cases. This can of course cause confusion to users. In terms of terminology, the phenomenon of diversity in the creation of this term should be given attention to ensure that the term used can be understood and practised by users because the term is related to the well-being of society. According to the Kasdan (2020), the terminology established to support the vocabulary of every science developed and the results analyse a term result in new terms and concepts that meet the diverse heritage preserve. Moreover, the creation of terms is formed through daily experience and according to the creativity of speakers and the local community (Kasdan, 2020).

Kasdan, Haroon, Pa, and Idrus (2017) found that the formation of the term gain of a partial sustain the vagaries of the Malay term which was formed but its formation was not done haphazardly but have patterns and systems regularly. Terms are formed 
to support the vocabulary of each knowledge developed. Although there are opinions that say that most of the terms in the past were formed spontaneously, there are methods that help the wise first create the term. Some studies show that the Malay community coined the term based on their experience interacting with nature. Tradition is not only among the Malays stopped in time, but also continuously until now. For example, through the method of formation of fauna names such as sesibur (sibursibur), pepatung (dragonfly), lelais (lais-lais) or sesumpah (sumpah-sumpah); and flora such as deduit (duit-duit), bebaru (barubaru), bebuas (buas-buas) or bebati (beti-beti) that appeared since ancient times, now terms such as liquid, hair, mouse, bulb, and window are used in various fields knowledge, including engineering and science and technology. The structural equation is not just based on imitation alone, instead, there is a formula that can certainly be explained. This article aims to show aspects and multiple partial patterns in the Malay language terminology, in addition to explaining the relationship between science and the creation of the term. Peel term concept described socioterminology approach, which combines data, analogy, philosophy, and cognition Malay speakers, not only can reveal the wisdom of Malay in determining the choice of terms but also highlight the Malay common sense. The analysis was carried out on 1,087 terms gain partial found in the corpus terms of Engineering and Science and Technology ( $\mathrm{S} \& \mathrm{~T}$ ) found that while the establishment of term gain of a partial sustains the vagaries of the Malay term which was formed but its formation was not done haphazardly, but has a pattern and a regular system (Kasdan et al., 2017).

Mohamad (2017) examine the new terms that are spread among the community and describe the aspects of its formation. Samples used in the study were obtained from papers in local online newspapers. This study adopted the General Guidelines for the Establishment of the term Malay Language to analyze the data that have been identified. The findings of the study show that a total of 64 terms in various fields were successfully collected. The study found that $30 \%$ of the Malay term fully formed, while $56 \%$ of the foreign language and $14 \%$ is a combination of Malay language and a foreign language.

\section{METHODOLOGY}

This survey study is an inference study using quantitative data that has been collected through questionnaires. The data obtained from the text content analysis and questionnaire form will be analysed and presented in the form of tables. The results of the analysis will be able to draw conclusions based on the objectives of the study that have been set. The data obtained were collected using a questionnaire that was distributed randomly through the WhatsApp application and was distributed to four public universities in four different states namely International Islamic University Malaysia (IIUM) Pagoh campus in Johor, Universiti Kebangsaan Malaysia (UKM) in Bangi, Selangor, University of Malaya (UM) in Kuala Lumpur and Universiti Perguruan Sultan Idris (UPSI) in Tanjung Malim, Perak. Data obtained randomly taken from a total of 200 respondents consists of all races of both sexes. The data collected randomly is also used to allow everyone to have the same opportunity to answer the question according to their knowledge. Our purpose in selecting public universities in different states is to ensure that the data obtained the requirements of the study. Due to respondents being in different states, researchers ensure that their level of knowledge of new terms during COVID-19 has reached one hundred per cent because the term is an official term that should be applied in daily life compared to other various terms. It aims to enhance the use of the right terminology in languages other than English. Researchers used press conferences as a medium of data collection. The COVID-19 press conference started on 23 March 2020 till now to inform the latest matters related to COVID-19. The speakers consisted of the Prime Minister (Tan Sri Muhyiddin Yassin), Director-General of Health (Dr. Noor Hisham), and Minister of Defence (Dato’ Sri Ismail Sabri Yaakob).

The main instrument used in this study is the questionnaire. This method is used to obtain quantitative data from respondents. Questionnaires in this study were used regarding the Dewan Bahasa dan Pustaka Dictionary to ensure that the term was officially used. Besides, the researcher also analyzed the text of the speech of the Prime Minister of Malaysia and the speech text of the Director of the Ministry of Health Malaysia to find new terms that are often used when announcing the new COVID-19 case situation in Malaysia. This questionnaire was modified based on the objective goals of the study. This questionnaire is divided into two parts, the first part is the demographic of the respondents which consist of three personal information such as gender, ages, and university, meanwhile, the second part is the list of new terms during COVID-19 which consists of 23 terms of COVID-19. The explanation of the questionnaire form is as in appendix 1.

\section{RESULTS AND ANALYSIS}

\subsection{Demographics Respondents}

Table 1 described the demographics of respondents consisting of gender, age, and university. Table 1 shows that this study involved 200 respondents consisting of 62 male respondents equivalent to $31 \%$, meanwhile female respondents amounted to 138 people equivalent to $69 \%$. Through pie chart 1 above, it can be concluded that the majority of respondents who answered the questionnaire were female. This is because the number of female students in Malaysian universities is more than male students.

Table 1

Respondent Gender

\begin{tabular}{clccc}
\hline Vol. & & Gender & Student & Percentage \\
\hline 1. & Male & 62 & 31 \\
\hline 2. & Female & 138 & 69 \\
\hline & Total & $\mathbf{2 0 0}$ & $\mathbf{1 0 0}$
\end{tabular}




\begin{tabular}{clccc}
\hline Vol. & & Ages & Students & Percentage \\
\hline 1 & $18-20$ years old & 32 & 16 \\
\hline 2 & $21-23$ years old & 142 & 71 \\
\hline 3 & $24-26$ years old & 26 & 13 \\
\hline Vol. & & Students & Percentage (\%) \\
\hline 1. & Universiti Islam Antarabangsa Malaysia & 50 & 25 \\
\hline 2. & Universiti Malaya & 50 & 25 \\
\hline 3. & Universiti Kebangsaan Malaysia & 50 & 25 \\
\hline 4. & Universiti Pendidikan Sultan Idris & 50 & 25 \\
\hline & Total & $\mathbf{2 0 0}$ & $\mathbf{1 0 0}$ \\
\hline
\end{tabular}

Table 1 shows that the percentage of the age of respondents ranging from age 18 to 26 years. A total of 32 students equivalent to $16 \%$ of respondents aged between 18 years to 20 years. Next, respondents aged 21 to 23 years have recorded a percentage of $71 \%$ equivalent to 142 respondents. Respondents aged 24 to 26 years, recorded a percentage of $13 \%$ equivalent to 26 respondents.

Based on Table 1, this study uses a total of 200 respondents from public universities, namely Universiti Islam Antarabangsa Malaysia (IIUM) Pagoh campus, Universiti Malaya (UM), Universiti Kebangsaan Malaysia (UKM), and Universiti Pendidikan Sultan Idris (UPSI) has answered this questionnaire. Through pie chart 3 above shows, the number of respondents from each university is the same which is $25 \%$ equivalent to 50 students from the university.

\subsection{Identify the new terminology of COVID-19}

A total of 23 new terms in COVID-19 obtained from the press conference were successfully identified during the data collection process. These terms were obtained from a press conference conducted during the COVID-19 pandemic, namely through a press conference of the Director of the Ministry of Health Malaysia. Next, Table 5 shows the new terms of COVID-19 and also attached the meaning of those terms. Table 5 show terms and definition in the Malay Language due to this research seeking student comprehension towards the new terms of COVID-19 in the Malay language.

\section{Table 2}

The New Terminology of COVID-19

\begin{tabular}{|c|c|c|}
\hline No & $\begin{array}{l}\text { COVID-19 new } \\
\text { terms }\end{array}$ & Definition \\
\hline 1. & $\begin{array}{l}\text { R-Naught } \\
\text { R-Naught }\end{array}$ & $\begin{array}{l}\text { Kebolehjangkitan sesuatu virus pada permulaan sesuatu wabak di dalam masyarakat. } \\
\text { The contagion of a virus at the beginning of an epidemic in a community. }\end{array}$ \\
\hline 2. & Pandemic & $\begin{array}{l}\text { Wabak yang sudah menular ke kawasan atau wilayah yang lebih luas malah ke pelbagai } \\
\text { benua dan ke seluruh dunia. } \\
\text { An epidemic that has spread to a region and even to various continents and around the world. }\end{array}$ \\
\hline 3. & Kluster & $\begin{array}{l}\text { Kejadian apabila berlakunya banyak kes jangkitan di sesuatu kawasan atau daripada sesuatu } \\
\text { kumpulan. } \\
\text { Occurrence when there are many cases of infection in an area or from a group. }\end{array}$ \\
\hline 4. & $\begin{array}{l}\text { Subkluster } \\
\text { Subcluster }\end{array}$ & $\begin{array}{l}\text { Kelompok kecil yang berada di dalam kumpulan besar di sesuatu kawasan. } \\
\text { Small groups that are in large groups in an area. }\end{array}$ \\
\hline & $\begin{array}{l}\text { Meratakan } \\
\text { lengkungan }\end{array}$ & $\begin{array}{l}\text { Mengelak peningkatan mendadak jumlah kes positif Covid-19 serta penularan jangkitan. } \\
\text { Prevent a sharp increase in the number of Covid-19 positive cases as well as the spread of } \\
\text { infection. }\end{array}$ \\
\hline
\end{tabular}

Flatten the curve

6. Penjejakan kontak Mengenal pasti mereka yang telah terdedah kepada mereka yang dijangkiti bagi mendapat maklumat lanjut tentang kontak atau pendedahan berkenaan.

Contact tracking

Identify those who have been exposed to those who are infected for more information about the contact or exposure.

7. Kuarantin kendiri Individu yang pernah berhubung dengan kes positif tetapi tidak dikenal pasti sebagai kontak rapat. Tidak dikenakan HSO \& tidak dipakaikan gelang. Perlu kuarantin diri \& pantau status kesihatan selama 14 hari.

Individuals who have been in contact with a positive case but have not been identified as close contacts. Not wearing HSO \& not wearing bracelets. They need to quarantine Self-quarantine themselves \& monitor health status for 14 days.

8. Aktiviti survelan Aktiviti survelan bertindak sebagai sistem amaran awal (early warning) dan pengesanan awal (early detection) bagi jangkitanCOVID-19 di Malaysia.

Surveillance activities Surveillance activities act as an early warning and early detection system for COVID-19 infection in Malaysia. 


\begin{tabular}{|c|c|c|}
\hline 9. & Triaging & $\begin{array}{l}\text { Penilaian dan penyaringan pesakit mengikut keperluan rawatan kecemasan dan evakuasi kes. } \\
\text { Evaluation and screening of patients according to the needs of emergency treatment and case } \\
\text { evacuation. }\end{array}$ \\
\hline 10. & $\begin{array}{l}\text { Operasi pematuhan } \\
\text { Compliance operation }\end{array}$ & $\begin{array}{l}\text { Pasukan petugas operasi pematuhan terdiri daripada } 14 \text { agensi kerajaan yang diberi kuasa } \\
\text { oleh Kementerian Kesihatan Malaysia (KKM) untuk pelaksanaan pematuhan PKPB. } \\
\text { The compliance operations task force consists of } 14 \text { government agencies authorized by the } \\
\text { Ministry of Health Malaysia (MOH) for the implementation of PKPB compliance. }\end{array}$ \\
\hline 11. & Penjarakan sosial & $\begin{array}{l}\text { Meningkatkan jarak fizikal antara manusia bagi mengelak jangkitan virus, melebihi satu } \\
\text { meter, malah hingga dua meter di sesetengah negara. } \\
\text { Increase the physical distance between humans to prevent viral infections, more than one } \\
\text { meter, even up to two meters in some countries. }\end{array}$ \\
\hline 12. & $\begin{array}{l}\text { Perintah kawalan } \\
\text { pergerakan }\end{array}$ & $\begin{array}{l}\text { Arahan atau peraturan yang dikenakan oleh kerajaan sesebuah negara bagi membataskan } \\
\text { pergerakan dan mengurangkan sosialisasi untuk mengekang penyebaran Covid-19. } \\
\text { Order or regulations imposed by the government of a country to restrict movement and } \\
\text { reduce socialization to curb the spread of Covid-19. }\end{array}$ \\
\hline
\end{tabular}

13. Penutup hidung dan Topeng yang mempunyai 3 lapisan untuk melindungi hidung dan mulut daripada penularan mulut COVID-19.

Face mask

The mask has 3 layers to protect the nose and mouth from COVID-19 transmission.

\begin{tabular}{|c|c|c|}
\hline 14. & $\begin{array}{l}\text { Pensanitasi tangan } \\
\text { Hand sanitizer }\end{array}$ & $\begin{array}{l}\text { Bahan yang berupa cecair atau gel yang digunakan untuk membersihkan bahan pencemaran } \\
\text { seperti kuman (bakteria, virus, kulat dan lain-lain) penyebab penyakit. } \\
\text { Substances in the form of liquids or gels are used to clean contaminants such as germs } \\
\text { (bacteria, viruses, fungi, etc.) that cause disease. }\end{array}$ \\
\hline 15. & Kuarantin & $\begin{array}{l}\text { Suatu pendekatan dalam perubatan di mana manusia, haiwan ataupun tumbuhan diasingkan } \\
\text { untuk tempoh tertentu mencegah dan mengehadkan penularan penyakit. } \\
\text { An approach in medicine in which humans, animals, or plants are isolated for a certain time } \\
\text { to prevent and limit the spread of disease. }\end{array}$ \\
\hline 16. & Vaksin & $\begin{array}{l}\text { Suatu persediaan biologi yang menyediakan pelalian aktif untuk penyakit tertentu. } \\
\text { A biological preparation that provides active immunization for certain diseases. }\end{array}$ \\
\hline
\end{tabular}

$\begin{array}{ll}\text { 17. Norma baharu } & \text { Amalan yang sebelum ini bukan amalan biasa akan menjadi kelaziman atau amalan biasa. } \\ & \text { Practices that were previously not common practice will become commonplace or common } \\ \text { New norms } & \text { practice. }\end{array}$

18. Penyebar senyap $\quad \begin{aligned} & \text { Seseorang yang tidak mengalami gejala sesuatu penyakit tetapi menjangkiti orang lain. } \\ & \text { A person who does not experience symptoms of a disease but infects others. }\end{aligned}$

Silent Spreader

19. Perintah kawalan diperketat (PKPD) Enhanced movement control order (EMCO)

\author{
PKPD termasuk: \\ EMCO included: \\ - semua penduduk dan pelawat di dalam kawasan dilarang keluar dari rumah mereka \\ semasa perintah itu; \\ all residents and visitors in the area are prohibited from leaving their \\ homes during the order;
}

- bukan penduduk dan pelawat dari luar kawasan tidak dibenarkan masuk ke kawasan yang tertakluk kepada perintah itu; non-residents and visitors from outside the area are not allowed to enter the area subject to the order;

- semua perniagaan ditutup; all businesses closed;

- bekalan makanan yang mencukupi akan diberikan oleh pihak berkuasa semasa 14 hari untuk semua penduduk; adequate food supply will be provided by the authorities during 14 days for all residents;

- pangkalan perubatan akan ditubuhkan di kawasan itu; a medical base will be established in the area;

- semua jalan ke kawasan itu disekat. all roads to the area are blocked.

20. Perebak utama
Superspreader Keadaan di mana seorang individu berupaya menjangkiti ramai orang. Conditions in which one individual is capable of infecting many people. 
21. Barisan hadapan

Frontliner

22. Peralatan

Perlindungan Diri

Personal Protective Equipment (PPE)

23. S.O.P Covid (standard operating procedure)
Pasukan polis, doktor, tentera dan lain-lain lagi yang mengawal dan melindungi masyarakat daripada dijangkiti penyakit berjangkit.

Police forces, doctors, soldiers, and others control and protect the community from being infected with infectious diseases.

Segala bentuk pakaian dan peralatan tambahan yang direkacipta untuk memberi perlindungan daripada bahaya.

All forms of clothing and additional equipment designed to protect from danger.

SOP dalam bahasa Melayu disebut Prosedur Operasi Standard. SOP bermaksud peraturan atau prosedur yang disusun oleh KKM, di mana semua peraturan perlu dipatuhi oleh masyarakat.

SOP in the Malay language is called Prosedur Operasi Standard. SOP means rules or procedures compiled by the $\mathrm{MOH}$, where all rules must be followed by the community

Source:

\subsection{Student Comprehension towards the New Terminology of COVID-19}

Based on objectives, the second objective is to seek the level of students' comprehension of the term COVID-19 which is often used during press conferences by the Director of the Ministry of Health Malaysia. Table 6 is an indicator of the level of comprehension of students from selected Universities. Table 3 also shows the total student comprehension of the selected COVID-19 terms.

Table 3

Total of Student Comprehension

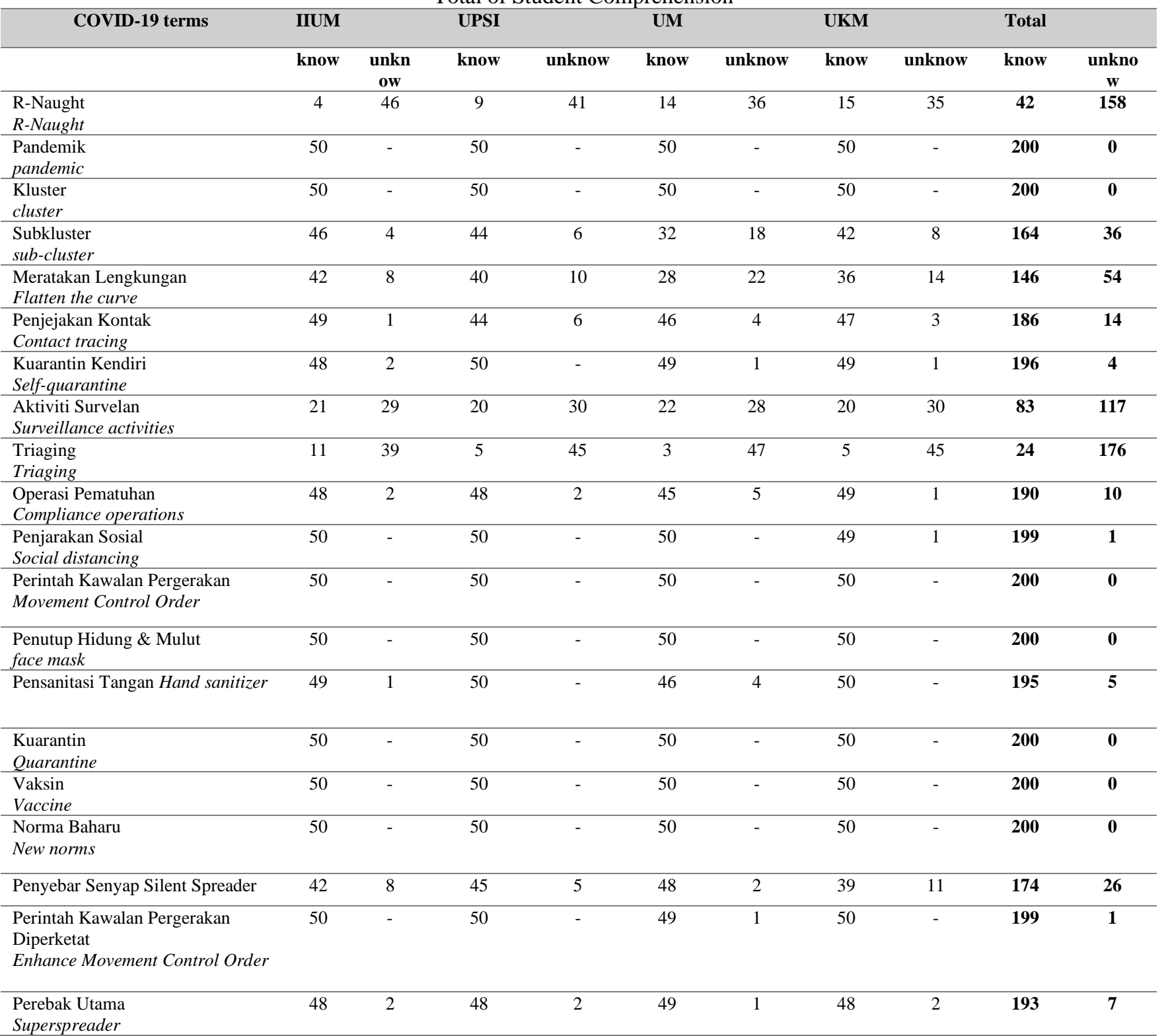




\begin{tabular}{|c|c|c|c|c|c|c|c|c|c|c|}
\hline $\begin{array}{l}\text { Barisan Hadapan } \\
\text { Frontliner }\end{array}$ & 50 & - & 50 & - & 50 & - & 50 & - & 200 & 0 \\
\hline $\begin{array}{l}\text { Peralatan Perlindungan Diri } \\
\text { Personal Protective Equipment } \\
\text { (P.P.E) }\end{array}$ & 46 & 4 & 45 & 5 & 27 & 23 & 46 & 4 & 164 & 36 \\
\hline $\begin{array}{l}\text { Prosedur Operasi Standard } \\
\text { Standard Operating Procedure } \\
(\text { S.O.P) }\end{array}$ & 47 & 3 & 50 & - & 50 & - & 50 & - & 197 & 3 \\
\hline $\begin{array}{l}\text { Jumlah } \\
\text { Total }\end{array}$ & 1001 & 149 & 998 & 152 & 958 & 192 & 995 & 155 & 3952 & 648 \\
\hline
\end{tabular}

Based on table 3, data shows student comprehension toward the new terms of COVID-19. Students from IIUM states the highest number of comprehension which is 1001, followed by UKM students, UPSI students and the last one is UM students. The terms of COVID-19 are not exactly known by students such as the terms of triaging, 'aktiviti survelan', and 'R-Naught'. These terms are exactly hard to understand and lexical meaning due to these terms still being new and explanations to these terms still not wisely.

\section{a. Triaging}

Triaging is defined as the assessment and screening of patients according to the needs of emergency treatment and case evacuation. This term is used and appears during COVID-19. The term triaging is seen as confusing to students' comprehension based on the questionnaire that has been conducted. Based on table 3, the term Triaging recorded the highest number of students who do not know compared to other terms with a total record of 176 out of a total of 200 students. This may be because the term is rarely used or heard in everyday communication. In terms of comparison, UM recorded the highest number who do not know the meaning of the Triaging term with a total of 47 students followed by UPSI and UKM which each recorded a total of 45 students, and followed by IIUM which is 39 students.

\section{b. R-Naught}

R-Naught is defined as the spread of a virus at the onset of an epidemic in society. The term R-Naught was popularized when the COVID-19 pandemic hit the world. This term is also used in the spread of viruses or other diseases (Mohamad et al., 2020). The term R-Naught also confuses students' understanding of the term R-Naught. Based on table 3, the term of R-Naught recorded the second-highest number of 158 students who do not know compared to the number of knowers which is 42 students as a result of addition from the four universities. In terms of comparison, IIUM found the highest number of students who do not know the meaning of the R-Naught term with a total of 46 students compared to UKM which recorded the lowest number of 35 students. Meanwhile, UPSI and UM respectively recorded as an unknown number of 41 and 36 students.

\section{c. Surveillance Activities}

Surveillance activities are defined as an early warning system and early detection for COVID-19 infection in Malaysia. Based on the findings of the study shows that students' understanding is seen to be almost equal, that is, the amount of understanding of the terms of surveillance activity is almost the same and the difference between known and unknown is not much different. Table 3 shows that many students still do not know the term of surveying activity or knowledge at a moderate level. There are a total of 117 students who do not know the term from the actual number of 200 students. This may be due to the term is rarely used or this term used with other names that cause awkwardness in the Malay language is heard. In terms of comparison, UPSI and UKM recorded the same highest number of 30 students who do not know the term of Surveying Activity compared to IIUM and UM which recorded a total of 29 and 28 students respectively and made a total of 83 students only know this term.

\section{d. Subcluster and Personal Protective Equipment (P.P.E)}

Subclusters are defined as small groups that are in large groups in an area. Meanwhile, PPE means all forms of clothing and additional equipment designed to protect from danger. Based on the findings, the student's understanding is seen as almost 60 per cent who know the meaning of the term compared to the remaining 40 per cent who may lack the meaning of subcluster and Personal Protective Equipment (P.P.E). Table 3 shows the level of understanding of students on the term Subcluster and Personal Protective Equipment (P.P.E) in the COVID-19 pandemic. Almost 60 percent of students from all four universities know the term subcluster and standard operating procedure. This can be proved through a bar graph where 46 students from IIUM received the highest number of knows followed by UPSI which is 44 students. Then, UKM was 42 , and UM with 32 . As a result, added that out of these four universities made a total of 164 students knew the meaning of these two terms.

\section{e. Flatten the curve}

Flatten the curve means avoiding a sharp increase in the number of positive covid-19 cases as well as the contagion of infection. In Malaysia, the front liners are constantly working hard every day to level the curve. Based on the study, the level of students' knowledge of the term levelling the curve is quite weak. This is said to be because the number of students who do not know is quite high over 50 people. Table 3 shows the level of understanding of students on the term flattens the curve in the COVID-19 pandemic. Based table 3 shows UM students have the highest number of students who do not know the meaning of the flatten the curve term of 22 compared to all three other public universities. This may be because the term in Malay is less used in daily communication and students prefer to use the term in other languages. Therefore, the term in this Malay language sounds 
awkward to them. However, the findings could still be proud of as 146 students from the added four universities knew the meaning of the term from a total of 200 .

\section{f. Silent Spreader}

In corpus data, silent spreaders are defined as a condition of a person who does not suffer from any symptoms of the disease but infects others unconsciously. This term applies a lot in English regardless of the Mass media nor social media. However, the table below shows the extent of the students' level of knowledge and sensitivity towards the meaning of the term. Table 3 found that students' knowledge level of silent spreaders achieved a satisfactory level as 174 students knew the term out of a total of 200 students. UM, students received the highest number of 48 students from UPSI at 45 and third and fourth place, IIUM students at 42, and UKM at 39. The term in English is seen to greatly influence the level of knowledge of students on the term used during Covid-19.

\section{g. Contact Tracking}

Contact tracking means a method to identify those who have been exposed to those infected to obtain information about the contact or disclosure. Based on table 3 shows a high level of student knowledge in contact tracking terms. This may be due to the widespread usage of terminology in Malay on every social media and mass media. The study found that 49 IIUM students knew the term was followed by students from UKM at 47. Meanwhile, students from UM and UPSI registered 46 and 44 students respectively. The total number of students who knew the term was 186 and only 14 students who still did not know the term contact tracking. This may be due to other language factors used other than Malay.

\section{h. Compliance Operation}

Compliance operations are defined as a compliance operations task force comprising 14 government agencies authorized by the Ministry of Health Malaysia (MOH) for the implementation of MCO compliance. Table 3 shows the number of students who understand and do not understand the term of compliance operations. Based on table 3, the study showed that students' knowledge level of compliance operational terms was very good as there were only 10 students out of the total 200 students who were arguably less accurate about the use of very widespread terms at this point in use since the covid-19 Pandemic. On average, there is a high amount of knowledge for this term, with 49 students from UKM students, 48 students from IIUM and UPSI, and 45 UM students.

\section{i. Hand Sanitizer, Standard Operating Procedure(S.O.P), Self-Quarantine, and Superspreader.}

Hand sanitization is known as substances purifying liquids or gels used to clean pollutants such as germs, bacteria, viruses, fungi, and others that cause disease. The standard operating procedure (SOP) in the Malay language is called Prosedur Operasi Standard. SOP means rules or procedures compiled by the $\mathrm{MOH}$, where all rules must be followed by the community. Selfquarantine means individuals who have been in contact with a positive case but have not been identified as close contacts. Not wearing HSO and not wearing bracelets. They need to quarantine themselves and monitor their health status for 14 days. Lastly, superspreaders are the conditions in which one individual is capable of infecting many people. All these terms are commonly used in daily communication. So, this study was successfully proved by the level of students' knowledge of the term reaching about 98 per cent. Student Comprehension Toward The Terms Of Hand Sanitizer, Standard Operating Procedure (Sop), Selfquarantine, and Superspreader. Based on table 3, the level of students' knowledge of these terms is very outstanding as there are about one of only two students who do not know the contents. On average, each university leaked the number of students who knew the meaning of the term very high. For example, UPSI and UKM students showed a hundred percent of hand sanitization terms. Students from UPSI and UM showed a total of one hundred percent for the term SOP. Meanwhile, for the term Superspreader of all three universities namely IIUM, UPSI and UKM each registered the same number of knows for 48.

\section{j. Enhanced movement control order (EMCO) and Social distancing.}

EMCO meaning all residents and visitors in the area are prohibited from leaving their homes during the order. Other than that, EMCO also cannot allow the non-residents and visitors from outside the area to enter the area subject to the order. Meanwhile, social distancing gives meaning for increasing the physical distance between humans to prevent viral infection, more than one meter, even up to two meters in some countries. Based on table 3, the level of students' knowledge of these terms is very excellent and as many as 9 percent of students dominate the meaning of the term because there is only one student who does not know the term of the total number of 200 students. This may be due to the use of Malay terms for EMCO and Social distancing very widely used and disseminated as well as in advertising posters. So, students can remember and identify the term.

\section{k. Movement Control Order (MCO), Face Mask, the New Norm, the Frontliner, Vaccines, and Quarantine.}

The findings of the study show that students from all four universities understand and know the terms of movement control orders, face masks, new norms, front liners, vaccines, and quarantine. This is due to the data obtained shows a higher number of people who know or understand these terms. The understanding of this term is due to its wide use and dissemination compared to other terms. Kasdan et al. (2020) and Mohamad et al. (2020) documented that commonly used, widely used terms will easily influence and be easily understood by society due to common factors. Table 3 also shows the total of 100 percent of students who knows and understand the terms of Movement Control Command (MCO), Face Mask, the New Norm, Frontliner, Vaccine, and Quarantine. This term is often used in daily communication and it is also used widely, easy to spread, and easy to understand in mass media and social media. 
Based on the final findings of the study, the researcher found that the percentage of students who do not know the terms RNaught (158), Surveillance Activities (117), and Triaging (176) is high compared to other terms such as front liner, quarantine, face mask, and vaccines. Most students prefer to use the term in English than the term of the Malay language as a mask, sanitisertizer, close contact, flatten the curve, and so on. Since the outbreak of the pandemic spread, a variety of terms containing mixed code was used because of the lack of use of those terms in the Malay language. This is due to this pandemic is still new and the formation of this term takes a long time and requires in-depth research. Furthermore, students only know the new term of COVID-19 in everyday conversation or widespread use in mass media or social media. So, through the results of this study, researchers found that many students still take it easy about most of the terms used in this COVID-19. Thus, with the study of these new terms, much research toward terminology will come and hopefully, the research would enhance the Malay vocabulary. The terminology research would continue so that it can help in expanding and enhancing vocabulary in the Malay language and standardize all terms and all fields.

\section{DISCUSSION}

Based on analysis and results, the finding shows that students understand the term COVID-19. The data show that the students' comprehension is very good based on the studies that have been conducted. However, there are some terms such as surveillance activities, triaging that is not understood or known by students. This is due to the use of such terms that are underused or rarely heard.

Frequent use will make it easier for students to understand and learn new terms. The same is true of the term COVID-19 which appeared after the virus hit the world. An understanding and comprehension of these terms are essential to provide an understanding of the phenomenon of the language that is plaguing. The phenomenon of language like this term is constantly evolving due to the rapid development of technology, science, multimedia, and so on. With the development of these areas, it will enrich and enhance the Malay language in line with the other language. The usage of terms that are tailored to the Malay language will give more strength, competitive with other languages in expressing various terms. It also allows the Malay language to try to express various fields with the use of the term in coordination with other fields. These are the impact of new terms of COVID-19 in the Malay language:

\section{a. New Terms Of COVID 19 Will Contribute To Malay Language Development}

The new term during covid 19 can contribute to the addition of new vocabulary in the Malay language and this shows the Malay language is still relevant in the present. This happens due to the urgent need to increase the vocabulary of the Malay language during this pandemic occurs. For example, 'aktiviti survelan' and 'meratakan lengkungan'. The addition of these new languages can also contribute to various fields such as science and technology. The existence of this new term is also a measure that shows that the users of the language have been at a stage of development and civilization.

\section{b. Make It Easier To Understand The Meaning Of The New Term For Malaysian}

Furthermore, the addition of the new term COVID-19 can also make it easier for the Malaysian community to understand what is presented during a press conference or in daily use. Malaysian society does not only consist of teenagers, but also the elderly who live in the village. Therefore, the addition of these new terms can facilitate the information that is to be conveyed to all generations of society. For example, the terms 'Perintah Kawalan Pergerakan' and 'penutup hidung dan mulut' greatly contributed to society understanding the true meaning of the word and this allows the community to obey the instructions that need to be followed during this pandemic.

\section{c. Affect The Identity Of The Malay Language}

The existence of a new term is giving a negative impact on the Malay language itself. This is because there is a group of people who like to use English terms in everyday conversation. Although, the word is a term in the Malay language. For instance, the words hand sanitiser, face mask, and front liners are more widely used than the terms 'pensanitasi tangan', 'penutup hidung dan muka' as well as 'barisan hadapan'. The use of new terms in Malay is underserved by society because they feel awkward to use that term. This will result in the loss of identity in the Malay language.

\section{d. Malaysian Society Does Not Understand The Use Of New Terms}

There is also a negative effect of the addition of this new term, the community cannot understand the true meaning of the term. As evidence, based on the studies reviewed the new terms such as 'R-naught' and 'triaging' got the highest rating in the category of words that are not understood by students. This is because the Malaysian community is less exposed to the use of the new term. Therefore, Malaysians tend to ignore the term and care less about the meaning of the term.

\section{CONCLUSION}

Terminology is an important language planning activity to ensure intellectual Malay is preserved as a language of knowledge and communication standards. In general, this study successfully identified 23 terms related to the COVID-19 pandemic in a press conference and examined students' understanding of the terms in COVID-19. In the context of COVID-19 terminology, the new terms issued by MOH and DBP need to be well understood by people so that the information will be delivered easily and smoothly.

\section{LIMITATIONS AND FUTURE RECOMMENDATIONS}

Please cite this article as: Saimon, A., Latif, N. A. A., Rahim, N. A., Yusoff, A. I. M., \& Mohammad, N. S. H. (2020). Students Comprehension To The New Terminology of Covid-19. Journal of Social Sciences and Economic Review, 3(1), 12-22. doi.org/10.36923/ijsser.v3i1.99 
There are a few limitations or confines in this research such as respondents in this research are confined to university students aged between 18 to 26 years old. Researchers also make the limitation towards only four selected universities which are International Islamic University Malaysia (IIUM), University Kebangsaan Malaysia (UKM), University Malaya (UM), and University Perguruan Sultan Idris (UPSI). The researcher has set the number of respondents as many as 200 students from all four universities in this research. The selected respondents are from the students who follow the course of Malay as the main course at the selected University. A total of 50 students from each university were selected. Selected students are not limited to gender, i.e. the selected gender is randomly using simple random sampling. Researchers have also set a time of two weeks to collect data from respondents.

The data obtained, namely, the terms used are based on the COVID-19 press conference chaired by Tan Sri Dr Mohd. Hisham Abdullah as the Director of the Ministry of Health Malaysia. The terms used during the press conference were later coordinated with Dewan Bahasa dan Pustaka. Each term used in the press conference will be matched to the term issued by Dewan Bahasa dan Pustaka.

In this research, there are a few weaknesses for future study such as comprehension of the meaning of COVID-19 terminology. That means, every term in COVID-19 has a significant meaning such as face mask, surveillance activities, triaging, selfquarantine, and so on. Based on this flaw, for future research, the researcher suggests future research which is the study about the meaning of the term in COVID-19. The finding will find that comprehension toward the meaning of COVID-19. The meaning of COVID-19 will reflect a true comprehension and understanding of COVID-19.

The second recommendation is the other researcher should be involved in the terminology field. The full research and abundance in this field would enrich the lexicon in the Malay language. Studies have linked this term will indirectly enrich, intensify, and make competitive Malay language and express the diversity of terminology in various fields. With a lot of research, the community will also better understand the terms used in expressing the concepts of technology, science, medicine, and so on. The final recommendations are studies related to the Malay language should be intensified the Malay language to remain relevant and successful particularly expresses various terms related to modernization. In addition to that, the study of the Malay language should be increased to thrive and be competitive.

\section{REFERENCES}

Azuan Mat Dehan, A., Azuwan Yaakob, N., \& Zakaria, J. y. (2014). Formation '5P' Work Movement in Malay terms. International Journal of Language Education and Applied Linguistics 1(1), 77-86. doi:https://doi.org/10.15282/ijleal.v1.421

Fage-Butler, A. M., \& Jensen, M. N. (2015). The relevance of existing health communication models in the email age: an integrative literature review. Communication \& medicine, 12(2), 117-128. doi:DOI: 10.1558/cam.18399

Kasdan, J. (2020). Creation of terminology and reason Malays. International Journal of the Malay World and Civilisation, 8(1), 3-16. doi:https://doi.org/10.17576/jatma-2020-0801-01

Kasdan, J., Baharuddin, R., \& Shamsuri, A. S. (2020). Covid-19 in the Corpus Of Malay Terminology: A Socio-terminological Analysis. GEMA Online ${ }^{\circledR}$ Journal of Language Studies, 20(3), 221-241. doi:http://dx.doi.org/10.17576/gema-20202003-13

Kasdan, J., Haroon, H. A., Pa, N. S. C., \& Idrus, Z. (2017). Partial Reduplication in Malay Terminology: A Socio-terminological Analysis. GEMA Online ${ }^{\circledR}$ Journal of Language Studies, 17(1), 183-202. doi:http://doi.org/10.17576/gema-2017-170111.

Mohamad, H. (2017). The formation of new terms: to what extent are they in line with the guidelines? Proceedings of the 2nd International Conference on Social Sciences and Humanities (PASAK 2017), 26-27 April. http://psasir.upm.edu.my/id/eprint/64476/

Mohamad, H., Malek, N. K. A., \& Abd. Razak, N. H. (2020). Formation of Health Science Terminology by Users in General Malay Language. GEMA Online Journal of Language Studies, 20(3), 96-112. doi:http://doi.org/10.17576/gema-20202003-06

Radzi, H. (2011). Self-Empowerment Malay: Absorption Issues Foreign Words. Jurnal Melayu, 6(1), 13-27. doi:https://ejournal.ukm.my/jmelayu/article/view/4969/2523

\section{Appendix}

Questionnaire design part A shows respondent background, and the second one which is part B shows respondent comprehension towards the new terms of COVID-19.

\begin{tabular}{lll}
\multicolumn{1}{c}{ Part } & & \multicolumn{1}{c}{ ITEMS } \\
\hline A: Demographic & 1. Gender \\
\cline { 2 - 3 } & 2. Age \\
\cline { 2 - 3 } & 3. University \\
\hline
\end{tabular}

B: Objectives Analysing students' comprehension of the new terms of COVID-19. List of terms:- 




\section{Author's Biodata:}

Aminuddin Saimon (PhD.): Assistant Professor at International Islamic University Malaysia, Pagoh Campus. He expertise in Semantics, Pragmatics and Linguistics. Many papers was published especially in Dewan Bahasa \& Pustaka magazine, ILS Journal, BITARA and Pendeta Journal.

Nazatul Aineena Abdul Latif: Student degree of Malay for Communication at International Islamic University Malaysia. Now, she is in the third years of her studies. Many achievements during her studies such as she is one of the community members for MLCOM, Bureau of International \& Culture, Bureau of Entrepreneur Division of KLMSS, tutor for Malay For International Students, IT community and more.

Nazihah Abd Rahim: Student degree of Malay for Communication at International Islamic University Malaysia. Now, she is in the third years of her studies. Many achievements during her studies such as she is one of the community members for MLCOM, Bureau of Intercultural, Bureau of Anjung Melayu and more.

Ainul Insyirah Mohd Yusoff : Student degree of Malay for Communication at International Islamic University Malaysia. Now, she is in the third years of her studies. Many achievements during her studies such as she is one of the community members for MLCOM, Vice President of Ikatan Mahasiswa Anak Melaka, Bureau of Anjung Melayu and more.

Nur Syazani Hanis Mohammad: Student degree of Malay for Communication at International Islamic University Malaysia. Now, she is in the third years of her studies. Many achievements during her studies such as she is one of the community members for MLCOM, committee of HARMONI MALAYSIA, Bureau of Entrepreneur Division of KLMSS and more. 